J urral PenddkanBabsadenSastra, V dume12, Nomr 1, April 2012

\title{
KABA: CERITA KLASIK YANG MENGANDUNG KEKELIRUAN DENGAN TOLOK UKUR ABS-SBK
}

\author{
Musril Zahari \\ STIE Indonesia Jakarta \\ Korespondensi: Jln. Kayu Jati Jakarta Timur 13220 \\ Pos-el: bagindo_mz@yahoo.com
}

\begin{abstract}
Abstrak
Kaba: Cerita Klasik Yang Mengandung Kekelinuan dengan Tolok Ukur ABS-SBK. Kajian ini menyajikan Kaba, sebuah cerita rakyat di masyarakat Minangkabau yang sudah ditulis dalam bentuk buku. Kaba biasanya disampaikan oleh seorang pencerita dengan diiringi musik sebagai pengantar. Banyak cerita kaba yang masih diakui dan dikenal keberadaannya di masyarakat Minangkabau, namun dalam kajian ini hanya disajikan dua cerita kaba: (1) Magek Manandin dan (2) Anggun Nan Tongga. Latar kedua cerita tersebut berisi larangan perjudian dengan mengikuti ketentuan ajaran Islam. Dalam Anggun Nan Tongga dikisahkan tentang syirik (menyekutukan Allah) yang dikecam dalam Islam. Kisah ini tidak dikenal baik karena bertentangan dengan filsafat hidup masyarakat Minangkabau: adat atau tradisi berdasarkan hukum Islam, hukum Islam berdasarkan Al-Quran, Hukum Islam memandu adat atau tradisi. Filosofi ini menjadi kesepakatan masyarakat Minangkabau dan dilarang diubah hingga kapan pun. Sayangnya, dalam kedua cerita Kaba ini, kisah tentang perjudian dan keyirikan dianggap sebagai sebuah kebenaran meskipun dalam beberapa ayat Al-Q uran dijelaskan sebagai sebuah pelanggaran (penyimpangan).
\end{abstract}

Kata Kunci: kaba, adat, syarak, Minangkabau, syirik, perjudian

\begin{abstract}
Kaba: Deviations of 0 ral Classic Story with ABS-SBK Rules. This study discusses kaba, the oral classic story in Minangkabau society that has been written as the book. The kaba is usually told by the story tellers accompanied by he music instruments. Many kabas exist in the Minangkabau community, but in this study I only discuss two kabas (1) Magek Manandin and (2) Anggun Nan Tongga. Based on both kabas, I found that the gambling forbidden by Islam as if allowable. Within Anggun Nan Tongga, there are many discourses which are syirik (do worship other than Allah) that is slammed by Islam. These discourses should have not existed because they oppose to the philosophy of life in Minangkabau: custom/tradition founded upon Islamic law, Islamic law is founded upon the Qur'an, Islamic law dictates customs/traditions. This philosophy as the agreement among Minangkabau people is forbidden to change forever. Ufortunately, in these two kabas, the discourses about the gambling and kesyirikan are regarded as if he truth even though so many verses in the Al-Q uran explain about these deviations.
\end{abstract}

Keywords: kaba, custom, syarak, Minangkabau, syirik, gambling

p-ISSN 1412-0712 | e-ISSN 2527-8312 